\title{
Researches on the Correlation Between Estrogen and Progesterone Receptors Expression and Disease-Free Survival of Endometrial Cancer
}

This article was published in the following Dove Press journal: Cancer Management and Research

\section{Siling Ren $\mathbb{D}^{1, *}$ \\ jingxian $\mathrm{Wu}\left(\mathbb{D}^{2, *}\right.$ \\ Wanchun Yin (D) \\ Qianqian Liao (D) \\ Sailan Gong $\mathbb{D}^{\prime}$ \\ Beibei Xuan (ID) \\ Xiaoling Mu (D)}

'Department of Gynecology, The First Affiliated Hospital of Chongqing Medical University, Chongqing 400016, People's Republic of China; ${ }^{2}$ Department of Pathology, Chongqing Medical University, Chongqing 400016, People's Republic of China

*These authors contributed equally to this work.
Correspondence: Xiaoling Mu

Department of Gynecology, The First Affiliated Hospital of Chongqing Medical University, Chongqing 4000I6, People's Republic of China

Email mxl@hospital.cqmu.edu.cn
Objective: In this study, 345 patients with endometrial carcinoma (EC) were selected to investigate the correlation between ER/PR status and the EC disease-free survival (DFS) rate.

Methods: The intensity and proportion of tumor cell expression of estrogen receptors and progesterone receptors (ER/PR) status of 345 postoperative tumor specimens in ECs were independently assessed semi-quantitatively by two pathologists using immunohistochemistry, the summed score ranged from 0 to 8 points was worked out by adding proportion score and intensity score based on the breast cancer hormone receptor immunohistochemical Allred scoring system. The association between DFS in ECs and ER/PR expression (intensity, proportion and summed score) was assessed using Cox regression analysis. Gene expression data were obtained from The Cancer Genome Atlas research network (TCGA).

Results: According to inclusion criteria, 201 type I and 144 type II EC patients were enrolled in this study. In the univariate analysis of type I endometrial carcinoma, the intensity, proportion and summed score of ER/PR status were significantly correlated with DFS. After adjusting for factors known to significantly impact survival, the influence of ER/ PR status on DFS is generally decreased but the correlation is still significant. In the univariate analysis of type II endometrial carcinoma, the intensity, proportion and summed score of ER/PR status were significantly correlated with DFS. After adjusting for factors known to significantly impact survival, the influence of ER status on DFS is generally decreased, but the correlation is still significant, the effect of PR expression on DFS is not statistically significant.

Conclusion: Higher ER/PR expression status was associated with better DFS in patients with type I endometrial cancer after adjusting for known factors that significantly affect survival. In patients with type II endometrial cancer, patients with positive ER expression were significantly associated with better DFS. However, the effect of PR expression on DFS was not statistically significant.

Keywords: endometrial cancer, endometrioid carcinoma, disease-free survival rate, hormone receptor status, ER, PR

\section{Introduction}

Endometrial cancer is one of the most common cancer overall of the female reproductive tract and its incidence is increasing. ${ }^{1}$ According to the World Health Organization (WHO) classification in 2014, endometrial carcinoma was classified as: type I, also called estrogen-related tumors, occurs most frequently in premenopausal and perimenopausal women. The typical histological types are grade 1 and 
grade 2 endometrioid adenocarcinoma, and usually respond to hormone therapy. Type II: also known as nonestrogen-related tumor, occurs mostly in postmenopausal women and are traditionally thought to be less dependent of estrogen stimulation, usually have a worse outcome, including grade 3 endometrioid carcinoma, endometrial serous carcinoma, clear cell carcinoma, undifferentiated carcinoma, neuroendocrine tumor and carcinosarcoma. ${ }^{2,3}$ Risk factors associated with prognosis include: FIGO stage (The International Federation of Gynecology and Obstetrics, FIGO, 2009), histological subtype, tumor grade, cervical stromal invasion, lymphovascular space invasion (LVSI), etc. In order to improve the prognosis of patients, physicians need to determine the risk factors for appropriate individualized treatment. However, about $20 \%$ of patients diagnosed as low risk disease will develop recurrent disease within 5 years. ${ }^{4}$ Thus, this assessment is still not enough to precisely identify all high-risk patients. We noticed that in some studies, the absence of ER/PR expression was also an independent predictor of poor prognosis in type II endometrial cancer. ${ }^{5-7}$ Although there is a lot of literature to support that hormone receptor expression is associated with prognosis, no accepted clinical guidelines to report the role of hormone receptor status in the prognosis of endometrial cancer, but estrogen- progesterone receptors appear to be promising prognostic biomarkers in the future. ${ }^{8,9}$

In breast cancer, ESR 1 and PGR gene polymorphism was found to be related to the ER/PR expression and prognosis. ${ }^{10}$ In TCGA research network, we discovered ESR1 gene mutations in patients with endometrial carcinoma are associated with worse DFS, the effect of PR on DFS is less significant (Figures 1 and 2, www.cbioportal.org). Therefore, we conducted an immunohistochemical study of ER/PR status to explore the correlation between ER/PR status and DFS in patients with endometrial carcinoma.

In this study, 345 patients with endometrial carcinoma were selected to investigate the correlation between ER/ PR status and the DFS of ECs.

\section{Materials and Methods Study Participants}

The institutional review board of institutional research ethics committee of the first affiliated hospital of Chongqing medical university approved this retrospective study in 2019. All procedures performed in studies involving human participants were in accordance with the Declaration of Helsinki. All participants had provided the written informed consent prior to participating in this study. Our research population comprised patients

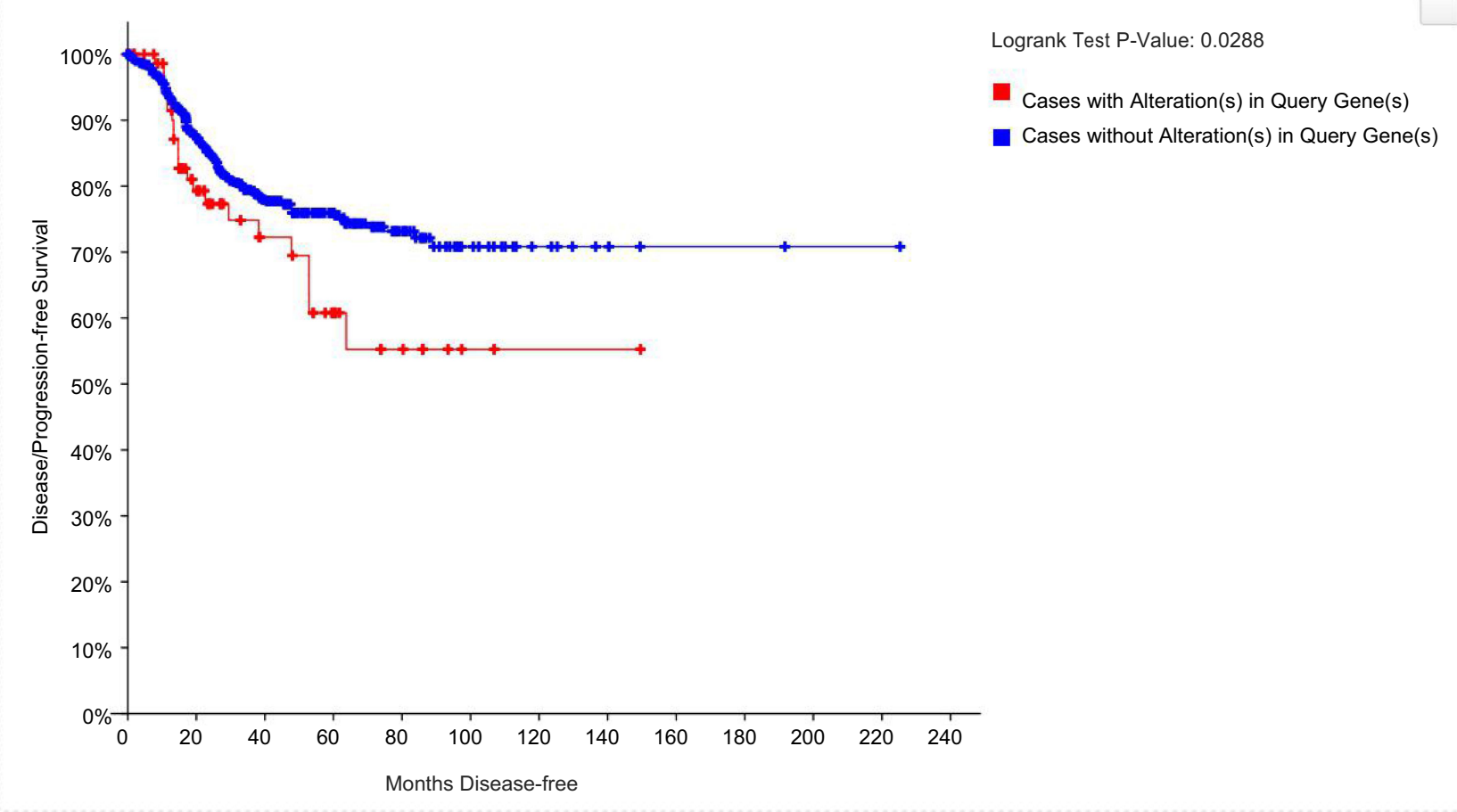

Figure I Disease-free Kaplan-Meier Estimate of patients with ESRI gene mutation. 
diagnosed with primary endometrial cancer from 2011 to 2016. All patients received total hysterectomy and bilateral salpingectomy and/or partial omentectomy, with or without pelvic and/or para-aortic lymph node excision; meanwhile, adjuvant chemoradiotherapy was determined based on high-risk factors. The patient exclusion criteria were as follows: 1. those who without available postoperative tumor paraffin sections; 2. patients who were unable to perform surgery; 3 . those who had received neoadjuvant chemotherapy; 4. those who died of other diseases; 5. patients with other concurrent tumors; 6 . those who were lost to follow-up. The enrolled clinicopathological variables included all available clinicopathological highrisk factors (Table 1).

The DFS was calculated from the date of surgery to date of recurrence, or censored on 31 September 2019. For patients enrolled in this study, Follow-up was conducted every 3 months for the first 2 years, every 6 months during the 3rd-5th years, and 12 months from the 6th year on.

\section{Immunohistochemistry (IHC) and Evaluation}

All tumor tissue specimens were obtained from the postoperative tumor tissues, and the specimens were

Table I Association Between Clinicopathologic Factors and DFS (Type I: $n=20$; and Type II: $n=144$ )

\begin{tabular}{|c|c|c|c|c|c|c|c|c|c|}
\hline \multirow[t]{2}{*}{ Parameter } & \multirow[t]{2}{*}{ Category } & \multicolumn{4}{|c|}{ Type I Endometrial Carcinoma } & \multicolumn{4}{|c|}{ Type II Endometrial Carcinoma } \\
\hline & & $\mathbf{N}$ & HR & $95 \% \mathrm{cl}$ & $\mathbf{P}$ & $\mathbf{N}$ & HR & $95 \% \mathrm{cl}$ & $\mathbf{P}$ \\
\hline \multirow[t]{2}{*}{ Age } & $<60 y$ & 154 & I & & & 70 & I & & \\
\hline & $\geq 60 y$ & 47 & 2.997 & $1.386-6.480$ & 0.201 & 74 & 3.997 & $1.386-9.480$ & 0.005 \\
\hline \multirow[t]{2}{*}{ Menopause } & No & 93 & 1 & & & 65 & I & & \\
\hline & Yes & 108 & 2.685 & $1.685-6.234$ & 0.607 & 79 & 2.685 & $1.685-6.234$ & 0.022 \\
\hline \multirow[t]{2}{*}{ Myometrial invasion } & $<1 / 2$ & 166 & I & & & 84 & I & & \\
\hline & $\geq 1 / 2$ & 35 & 2.791 & $1.327-5.872$ & 0.429 & 60 & 2.791 & $1.327-5.872$ & 0.007 \\
\hline \multirow[t]{2}{*}{ Cervical stromal invasion } & Absent & 161 & 1 & & & 113 & I & & \\
\hline & Present & 40 & 2.182 & $|.037-4.59|$ & 0.015 & 31 & 2.182 & $|.037-4.59|$ & 0.051 \\
\hline \multirow[t]{2}{*}{ LVSI } & Absent & 188 & 1 & & & 118 & I & & \\
\hline & Present & 13 & $\mathrm{I} .794$ & I.437-4.870 & 0.597 & 26 & 1.794 & $1.193-4.870$ & 0.597 \\
\hline \multirow[t]{2}{*}{ Lymph node metastasis } & Absent & 193 & 1 & & & 110 & 1 & & \\
\hline & Present & 8 & 2.624 & $2.265-7.964$ & 0.545 & 34 & 5.624 & $2.265-13.964$ & 0.001 \\
\hline \multirow[t]{4}{*}{ FIGO stage } & I & 144 & 1 & & & 88 & I & & \\
\hline & II & 42 & 2.562 & $1.744-8.818$ & & 19 & 1.414 & $1.094-5.08 \mid$ & \\
\hline & III & 14 & 6.513 & $1.904-12.275$ & & 33 & 5.520 & $2.547-11.963$ & \\
\hline & IV & I & 9.560 & $2.63 I-22.768$ & 0.007 & 4 & 7.878 & $2.729-25.901$ & $<0.001$ \\
\hline \multirow[t]{2}{*}{ Peritoneal cytology } & Absent & 193 & I & & & 107 & & & \\
\hline & Present & 8 & 3.437 & $|.566-8.65|$ & 0.446 & 37 & 1.437 & $|.256-3.65|$ & 0.446 \\
\hline \multirow[t]{2}{*}{ Tumor location } & Fundus & 156 & I & & & 96 & I & & \\
\hline & Lower uterine segment & 45 & 3.199 & $1.178-8.683$ & 0.021 & 48 & 1.941 & $1.345-3.986$ & 0.071 \\
\hline \multirow[t]{2}{*}{ Tumor size } & $<2(\mathrm{~cm})$ & 86 & 1 & & & 31 & 1 & & \\
\hline & $\geq 2(\mathrm{~cm})$ & 115 & 1.076 & $1.511-2.966$ & 0.888 & 113 & 1.332 & $1.141-3.470$ & 0.557 \\
\hline \multirow[t]{2}{*}{ Lymph node excision } & Yes & 184 & 1 & & & 125 & I & & \\
\hline & No & 17 & 1.749 & $1.527-7.143$ & 0.589 & 19 & 3.300 & $1.527-7.143$ & 0.002 \\
\hline \multirow[t]{2}{*}{ Adjuvant therapy } & Yes & 108 & I & & & 122 & I & & \\
\hline & No & 93 & 3.628 & $|| .7|-8.65|$ & 0.030 & 22 & 1.628 & $|.270-4.65|$ & 0.362 \\
\hline \multirow[t]{2}{*}{ Risk classification } & Low & 138 & I & & & & & & \\
\hline & Intermediate-high risk & 63 & 4.314 & $1.494-12.454$ & 0.007 & & & & \\
\hline
\end{tabular}

Abbreviations: N, number; HR, hazard ratio; 95\% cl, 95\% confidence interval; P, P-value. 
Table 2 ROC Curve Analysis for Association of ER and PR Score and ER/PR Combined Score and DFS

\begin{tabular}{|c|l|l|l|l|}
\hline & AUC & SE & $95 \% \mathbf{C I}$ & $\mathbf{P}$ \\
\hline Type I endometrial cancer & & & & \\
ER average proportion & 0.860 & 0.067 & $0.675-0.942$ & 0.001 \\
ER average intensity & 0.864 & 0.070 & $0.627-0.855$ & 0.003 \\
ER average summed score & 0.876 & 0.061 & $0.697-0.946$ & $<0.00$ I \\
PR average proportion & 0.733 & 0.087 & $0.553-0.873$ & 0.038 \\
PR average intensity & 0.687 & 0.084 & $0.522-0.831$ & 0.041 \\
PR average summed score & 0.758 & 0.082 & $0.598-0.878$ & 0.036 \\
\hline Type II endometrial cancer & & & & \\
ER average proportion & 0.836 & 0.063 & $0.613-0.930$ & 0.003 \\
ER average intensity & 0.824 & 0.067 & $0.694-0.905$ & 0.004 \\
ER average summed score & 0.837 & 0.063 & $0.714-0.936$ & 0.003 \\
PR average proportion & 0.709 & 0.071 & $0.569-0.849$ & 0.160 \\
PR average intensity & 0.695 & 0.074 & $0.550-0.840$ & 0.229 \\
PR average summed score & 0.710 & 0.071 & $0.571-0.850$ & 0.162 \\
\hline
\end{tabular}

Abbreviations: AUC, Area under the curve; SE, Standard Error of Mean; $95 \% \mathrm{Cl}$, confidence interval. formalin-fixed and paraffin-embedded. The high cell density and optimal tumor-fixation regions were selected from the paraffin sections. ER/PR expression was assessed using the following commercially available antibodies by IHC:ER (clone SP1, Denmark), PgR (clone IE2, Denmark). The ER/PR DAB Detection Kit and color developing kit were purchased from Thermo Scientific, the Ventana NexES Staining System (USA) was used to stain the progestogen tissue sections, and the AutostainerLink48 Staining System (USA) was used to stain the estrogen tissue sections. The sections were $5 \mathrm{~mm}$ in thickness, and the tissue block was counter-stained with hematoxylin II and bluing agent, followed by mounting. Normal endometrial tissue staining was set as an internal positive control to avoid false-negative results. Exclusion criteria for paraffin sections: 1) the staining was located at cytoplasm

Table 3 The Association Between ER/PR Proportion, Intensity, Summed Score and DFS in Type I Endometrial Carcinoma

\begin{tabular}{|c|c|c|c|c|c|c|c|c|c|c|}
\hline Parameter & $\begin{array}{l}\text { Tumor } \\
\text { Hormone } \\
\text { Receptor } \\
\text { Expression }\end{array}$ & $\mathbf{N}$ & $\begin{array}{l}\text { Crude } \\
\text { HR }\end{array}$ & $\begin{array}{l}95 \% \\
\text { Confidence } \\
\text { Limits }\end{array}$ & $\begin{array}{l}\text { Adjusted }^{a} \\
\text { HR }\end{array}$ & $\begin{array}{l}95 \% \\
\text { Confidence } \\
\text { Limits }\end{array}$ & $\begin{array}{l}\text { Adjusted }^{b} \\
\text { HR }\end{array}$ & $\begin{array}{l}95 \% \\
\text { Confidence } \\
\text { Limits }\end{array}$ & $\begin{array}{l}\text { Adjusted }^{c} \\
\text { HR }\end{array}$ & $\begin{array}{l}95 \% \\
\text { Confidence } \\
\text { Limits }\end{array}$ \\
\hline $\begin{array}{l}\text { ER proportion } \\
\text { score }\end{array}$ & $\begin{array}{l}\text { High: } \geq 3.5 \\
\text { Low: }<3.5\end{array}$ & $\begin{array}{l}143 \\
58\end{array}$ & $\begin{array}{l}1 \\
4.739\end{array}$ & $\begin{array}{l}2.024-15.547 \\
P=0.004\end{array}$ & $\begin{array}{l}1 \\
3.891\end{array}$ & $\begin{array}{l}1.333-11.363 \\
P=0.013\end{array}$ & $\begin{array}{l}1 \\
3.484\end{array}$ & $\begin{array}{l}\text { I.I53-10.526 } \\
P=0.027\end{array}$ & $\begin{array}{l}1 \\
4.237\end{array}$ & $\begin{array}{l}I .563-10.517 \\
P=0.080\end{array}$ \\
\hline $\begin{array}{l}\text { ER intensity } \\
\text { score }\end{array}$ & $\begin{array}{l}\text { High: } \geq 0.5 \\
\text { Low: }<0.5\end{array}$ & $\begin{array}{l}188 \\
13\end{array}$ & $\begin{array}{l}1 \\
6.060\end{array}$ & $\begin{array}{l}1.945-15.197 \\
P=0.020\end{array}$ & $\begin{array}{l}1 \\
5.263\end{array}$ & $\begin{array}{l}1.616-17.241 \\
P=0.060\end{array}$ & $\begin{array}{l}1 \\
3.413\end{array}$ & $\begin{array}{l}1.992-11.765 \\
P=0.026\end{array}$ & $\begin{array}{l}1 \\
4.950\end{array}$ & $\begin{array}{l}|.745-13.65| \\
P=0.007\end{array}$ \\
\hline $\begin{array}{l}\text { ER summed } \\
\text { score }\end{array}$ & $\begin{array}{l}\text { High: } \geq 4.5 \\
\text { Low: }<4.5\end{array}$ & $\begin{array}{l}|4| \\
60\end{array}$ & $\begin{array}{l}1 \\
4.950\end{array}$ & $\begin{array}{l}1.718-14.547 \\
P=0.003\end{array}$ & $\begin{array}{l}1 \\
4.219\end{array}$ & $\begin{array}{l}1.466-12.159 \\
P=0.080\end{array}$ & $\begin{array}{l}1 \\
3.690\end{array}$ & $\begin{array}{l}|.223-| 1.231 \\
P=0.020\end{array}$ & $\begin{array}{l}1 \\
4.570\end{array}$ & $\begin{array}{l}1.095-15.615 \\
P=0.005\end{array}$ \\
\hline $\begin{array}{l}\text { PR proportion } \\
\text { score }\end{array}$ & $\begin{array}{l}\text { High: } \geq 3.5 \\
\text { Low: }<3.5\end{array}$ & $\begin{array}{l}126 \\
39\end{array}$ & $\begin{array}{l}1 \\
4.000\end{array}$ & $\begin{array}{l}1.237-8.620 \\
P=0.006\end{array}$ & $\begin{array}{l}1 \\
3.378\end{array}$ & $\begin{array}{l}1.259-9.009 \\
P=0.440\end{array}$ & $\begin{array}{l}1 \\
3.484\end{array}$ & $\begin{array}{l}\text { I.307-9.346 } \\
P=0.032\end{array}$ & $\begin{array}{l}1 \\
3.330\end{array}$ & $\begin{array}{l}1.132-8.886 \\
P=0.013\end{array}$ \\
\hline $\begin{array}{l}\text { PR intensity } \\
\text { score }\end{array}$ & $\begin{array}{l}\text { High: } \geq 0.5 \\
\text { Low: }<0.5\end{array}$ & $\begin{array}{l}186 \\
15\end{array}$ & $\begin{array}{l}1 \\
3.389\end{array}$ & $\begin{array}{l}\text { I.742-7.854 } \\
P=0.035\end{array}$ & $\begin{array}{l}1 \\
4.201\end{array}$ & $\begin{array}{l}\text { I.335-14.095 } \\
P=0.020\end{array}$ & $\begin{array}{l}1 \\
2.695\end{array}$ & $\begin{array}{l}I .3 \mid 7-8.547 \\
P=0.042\end{array}$ & $\begin{array}{l}1 \\
4.255\end{array}$ & $\begin{array}{l}1.842-8.362 \\
P=0.016\end{array}$ \\
\hline $\begin{array}{l}\text { PR summed } \\
\text { score }\end{array}$ & $\begin{array}{l}\text { High: } \geq 4.5 \\
\text { Low: }<4.5\end{array}$ & $\begin{array}{l}165 \\
36\end{array}$ & $\begin{array}{l}1 \\
4.000\end{array}$ & $\begin{array}{l}\text { I.237-8.620 } \\
P=0.006\end{array}$ & $\begin{array}{l}1 \\
4.219\end{array}$ & $\begin{array}{l}I .558-12.346 \\
P=0.035\end{array}$ & $\begin{array}{l}1 \\
4.032\end{array}$ & $\begin{array}{l}I .5 \mid I-10.753 \\
P=0.025\end{array}$ & $\begin{array}{l}1 \\
3.968\end{array}$ & $\begin{array}{l}1.778-10.112 \\
P=0.013\end{array}$ \\
\hline $\begin{array}{l}\text { ER high/PR high } \\
\text { ER high/PR low } \\
\text { ER low/PR high } \\
\text { ER low/PR low }\end{array}$ & & $\begin{array}{l}123 \\
18 \\
42 \\
18\end{array}$ & $\begin{array}{l}1 \\
3.245 \\
4.261 \\
7.947\end{array}$ & $\begin{array}{l}1.538-16.524 \\
1.071-17.851 \\
3.472-20.022 \\
P=0.012\end{array}$ & $\begin{array}{l}\text { I } \\
3.684 \\
3.728 \\
6.573\end{array}$ & $\begin{array}{l}\text { I.889-I5.632 } \\
\text { I.596-20.783 } \\
\text { I.596-20.783 } \\
P=0.016\end{array}$ & $\begin{array}{l}1 \\
3.395 \\
3.763 \\
6.599\end{array}$ & $\begin{array}{l}1.788-14.617 \\
1.673-20.187 \\
2.285-25.328 \\
P=0.020\end{array}$ & $\begin{array}{l}1 \\
3.823 \\
3.823 \\
6.078\end{array}$ & $\begin{array}{l}1.664-14.379 \\
1.053-18.498 \\
2.730-20.945 \\
P=0.015\end{array}$ \\
\hline
\end{tabular}

Notes: ${ }^{\text {a} A d j u s t e d ~ f o r ~ L y m p h ~ n o d e ~ e x c i s i o n, ~ A d j u v a n t ~ t h e r a p y . ~}{ }^{\mathrm{B}}$ Adjusted for FIGO stage (2009 criteria). ${ }^{\mathrm{C}}$ Adjusted for Risk classification. 
rather than cell nucleus; 2) Tumor nuclei were major destroyed or lost (the paraffin section or tissue block should be replaced for re-staining or further analysis).

The ER/PR receptor expression status was scored by two experienced pathologists independently using digital images via the Aperio ePathology (Germany) scanning machine at 20x resolution who were blind to the patient clinicopathological data and clinical outcomes. In case of disagreement, paraffin blocks need to be reassessed and discussed to reach a consensus.

- Each paraffin section was scored on the basis of three criteria: 1) Proportion Scores Criteria Percentage of tumor cells stained positive: $0=$ no staining; $1 \leq 1 \%$ staining, $2=2-10 \%$ staining; $3=11-33 \%$ staining; $4=34-66 \%$ staining, and $5=67-100 \%$ staining. 2) Intensity Score Criteria - The staining intensity of tumor cells: $0=$ no staining; $1=$ weak staining; $2=$ intermediate staining, and $3=$ strong staining; 3 ) The summed score ranged from 0 to 8 points was worked out by adding proportion score and intensity score based on the breast cancer hormone receptor immunohistochemical Allred scoring system. ${ }^{11,12}$

\section{TCGA Cohort}

Data on DFS and publicly available gene expression in 1800 cases of endometrial carcinoma were obtained from project of TCGA research network in October 2019.

\section{Statistical Analysis}

The SPSS 23.0 software was used for statistical analyses. The receiver operating characteristic curve (ROC) analysis was conducted to evaluate the receptor expression state diagnostic performance for DFS in patients with endometrial cancer (Table 2); besides, the optimal cutoff value was determined by the Youden's index. Cox regression analysis was used to evaluate the relationship between DFS and hormone receptor expression (intensity, proportion and summed score), and to obtain crude and adjusted hazard ratios (HRs) and 95\% confidence intervals (CIs) for

Table 4 The Association Between ER/PR Proportion, Intensity, Summed Score and DFS in Type II Endometrial Carcinoma

\begin{tabular}{|c|c|c|c|c|c|c|c|c|}
\hline Parameter & $\begin{array}{l}\text { Tumor Hormone } \\
\text { Receptor Expression }\end{array}$ & $\mathbf{N}$ & $\begin{array}{l}\text { Crude } \\
\text { HR }\end{array}$ & $\begin{array}{l}95 \% \\
\text { Confidence } \\
\text { Limits }\end{array}$ & $\begin{array}{l}\text { Adjusted }^{a} \\
\text { HR }\end{array}$ & $\begin{array}{l}95 \% \\
\text { Confidence } \\
\text { Limits }\end{array}$ & $\begin{array}{l}\text { Adjusted }^{b} \\
\text { HR }\end{array}$ & $\begin{array}{l}95 \% \\
\text { Confidence } \\
\text { Limits }\end{array}$ \\
\hline ER proportion & $\begin{array}{l}\text { High: } \geq 1 \\
\text { Low: }<1\end{array}$ & $\begin{array}{l}95 \\
49\end{array}$ & $\begin{array}{l}1 \\
4.149\end{array}$ & $\begin{array}{l}2.024-8.547 \\
p<0.001\end{array}$ & $\begin{array}{l}1 \\
3.247\end{array}$ & $\begin{array}{l}1.117-8.547 \\
P=0.016\end{array}$ & $\begin{array}{l}\text { I } \\
2.57 \mid\end{array}$ & $\begin{array}{l}1.321-5.747 \\
P=0.021\end{array}$ \\
\hline ER intensity & $\begin{array}{l}\text { High: } \geq 0.5 \\
\text { Low: }<0.5\end{array}$ & $\begin{array}{l}94 \\
50\end{array}$ & $\begin{array}{l}1 \\
4.000\end{array}$ & $\begin{array}{l}1.945-8.197 \\
p<0.001\end{array}$ & $\begin{array}{l}1 \\
3.106\end{array}$ & $\begin{array}{l}1.183-8.130 \\
P=0.0021\end{array}$ & $\begin{array}{l}1 \\
2.304\end{array}$ & $\begin{array}{l}1.746-5.263 \\
P=0.037\end{array}$ \\
\hline $\begin{array}{l}\text { ER summed } \\
\text { score }\end{array}$ & $\begin{array}{l}\text { High: } \geq 1.5 \\
\text { Low: }<1.5\end{array}$ & $\begin{array}{l}95 \\
49\end{array}$ & $\begin{array}{l}1 \\
4.149\end{array}$ & $\begin{array}{l}2.024-8.547 \\
p<0.001\end{array}$ & $\begin{array}{l}1 \\
3.247\end{array}$ & $\begin{array}{l}1.117-8.547 \\
P=0.016\end{array}$ & $\begin{array}{l}\mathrm{I} \\
2.57 \mathrm{I}\end{array}$ & $\begin{array}{l}1.321-5.747 \\
P=0.021\end{array}$ \\
\hline PR proportion & $\begin{array}{l}\text { High: } \geq 3.5 \\
\text { Low: }<3.5\end{array}$ & $\begin{array}{l}51 \\
93\end{array}$ & $\begin{array}{l}1 \\
2.311\end{array}$ & $\begin{array}{l}1.237-8.620 \\
P=0.014\end{array}$ & $\begin{array}{l}1 \\
2.500\end{array}$ & $\begin{array}{l}1.112-8.929 \\
P=0.440\end{array}$ & $\begin{array}{l}\text { I } \\
2.445\end{array}$ & $\begin{array}{l}1.2|3-6.7| 1 \mid \\
P=0.083\end{array}$ \\
\hline PR intensity & $\begin{array}{l}\text { High: } \geq 0.5 \\
\text { Low: }<0.5\end{array}$ & $\begin{array}{l}84 \\
60\end{array}$ & $\begin{array}{l}1 \\
2.802\end{array}$ & $\begin{array}{l}0.942-7.854 \\
P=0.023\end{array}$ & $\begin{array}{l}1 \\
1.593\end{array}$ & $\begin{array}{l}1.249-4.016 \\
P=0.157\end{array}$ & $\begin{array}{l}\mathrm{I} \\
\mathrm{I} .174\end{array}$ & $\begin{array}{l}1.213-6.711 \\
P=0.676\end{array}$ \\
\hline $\begin{array}{l}\text { PR summed } \\
\text { score }\end{array}$ & $\begin{array}{l}\text { High: } \geq 4.5 \\
\text { Low: }<4.5\end{array}$ & $\begin{array}{l}52 \\
92\end{array}$ & $\begin{array}{l}1 \\
2.436\end{array}$ & $\begin{array}{l}1.325-8.928 \\
P=0.016\end{array}$ & $\begin{array}{l}1 \\
2.500\end{array}$ & $\begin{array}{l}1.112-8.929 \\
P=0.342\end{array}$ & $\begin{array}{l}1 \\
2.488\end{array}$ & $\begin{array}{l}1.525-6.849 \\
P=0.078\end{array}$ \\
\hline $\begin{array}{l}\text { ER high/PR high } \\
\text { ER high/PR low } \\
\text { ER low/PR low }\end{array}$ & & $\begin{array}{l}50 \\
42 \\
52\end{array}$ & $\begin{array}{l}1 \\
1.556 \\
5.491\end{array}$ & $\begin{array}{l}1.493-4.912 \\
2.058-14.651 \\
P=0.011\end{array}$ & $\begin{array}{l}1.426 \\
3.646\end{array}$ & $\begin{array}{l}1.968-13.730 \\
1.369-16.106 \\
P=0.016\end{array}$ & $\begin{array}{l}1 \\
2.488 \\
3.247\end{array}$ & $\begin{array}{l}1.133-9.303 \\
1.465-15.010 \\
P=0.027\end{array}$ \\
\hline
\end{tabular}

Notes: ${ }^{2}$ Adjusted for age (>60y), Lymph node metastasis. ${ }^{\mathrm{b}}$ Adjusted for age (>60y), Lymph node excision, FIGO stage (2009 criteria). 


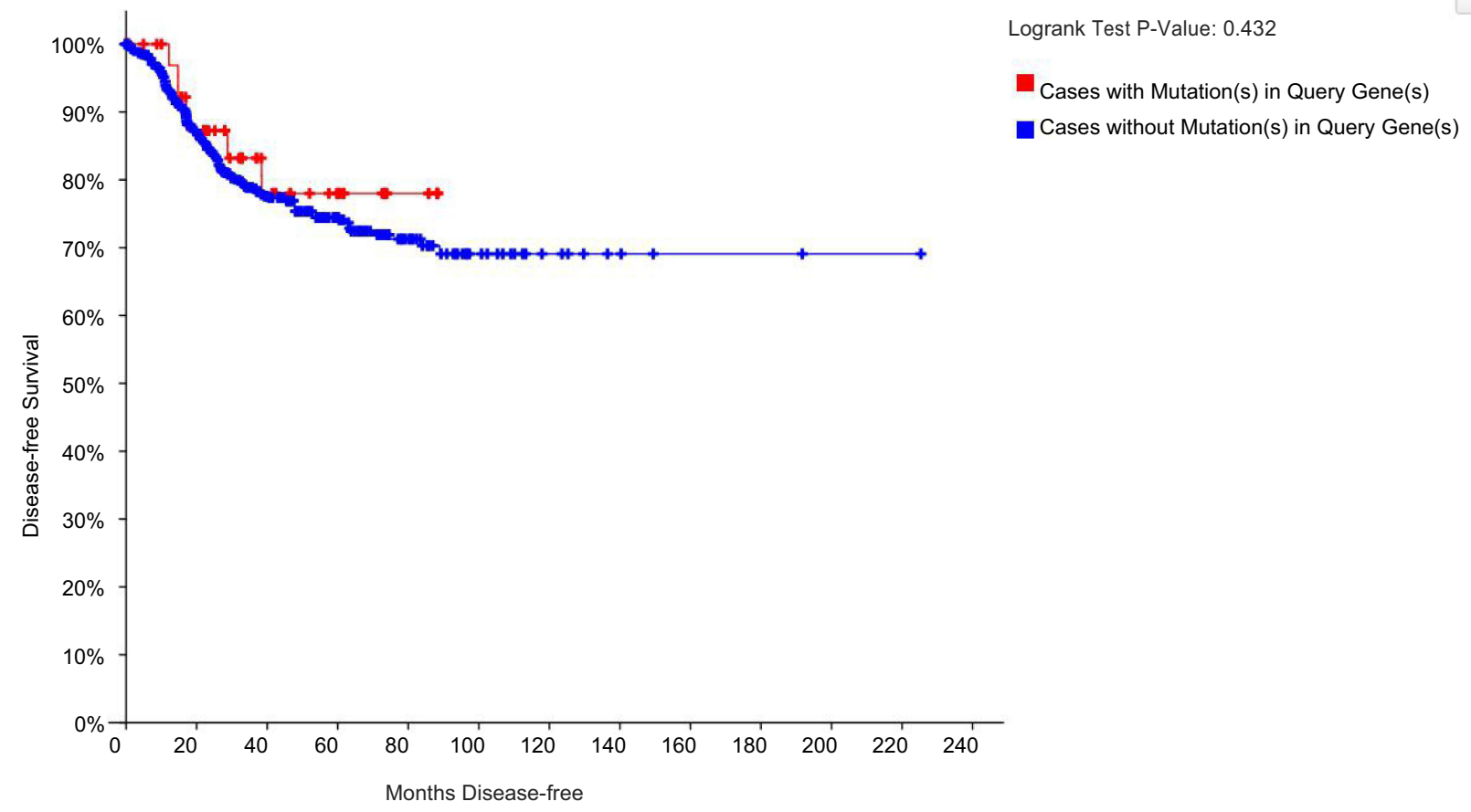

Figure 2 Disease-free Kaplan-Meier Estimate of patients with PGR gene mutation.

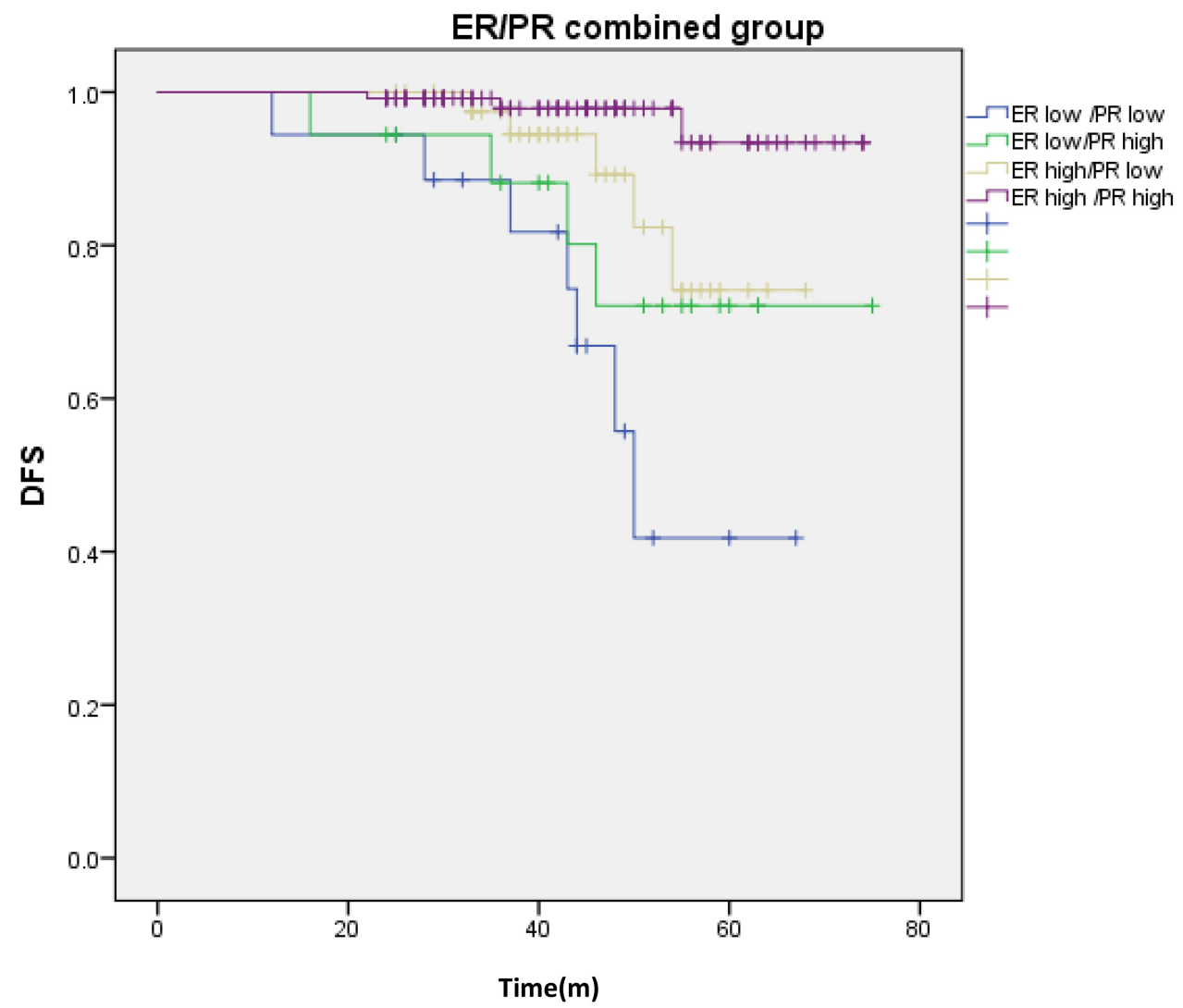

Figure 3 Estimated DFS for Type I endometrial cancer $(n=20 I)$ according to ER/PR status (Kaplan Meier estimation). Estimated DFS for according to ER/PR combined group. Logrank Test $P$ value: $<0.001$. Time $(m)$ DFS, Disease. 
endometrial cancer (Tables 3 and 4). The Kaplan-Meier analysis and Log-rank test were adopted to evaluate survival probabilities (Kaplan-Meier curves for ER and PR expression are plotted using summed score group). $\mathrm{P}$ value less than 0.05 was considered statistically significant.

\section{Results}

Gene expression data obtained from the TCGA research network showed that patients in the subgroup of ESR1 gene mutation had worse DFS, and the effect of GPR gene mutation on DFS was not statistically significant $(\mathrm{P}<0.001$ VS $\mathrm{P}=0.476)$.

The final analysis includes data from 345 patients with endometrial cancer. Table 1 presents the patient and tumor characteristics. The median follow-up time was 46.5 months (range, 1-93 months). During follow-up, 18 type I and 22 type II endocardial cancer patients experienced a relapse.
Amongst the clinicopathologic factors assessed by univariate analysis for type I endometrial cancer, FIGO stage $(\mathrm{P}=0.007)$, risk classification $(\mathrm{P}=0.007)$, cervical stromal invasion $(\mathrm{P}=0.015)$, tumor location $(\mathrm{P}=0.021)$ was the parameter that had the impact on DFS of patients with endometrial cancer (Table 1). Lower ER/PR expression, whether in intensity, proportion or summed score group, was associated with worse DFS in crude analyses. In the combined ER/PR states group, DFS shows significant advantages in the ER high/PR high group, followed by ER high/PR low, ER low/ PR high, ER low/PR low group (Table 3 and Figure 3). In order to avoid multicollinearity, we chose different variables and designed three different Cox regression models to evaluate the correlation between ER/PR states and DFS under different adjustment factors (Table 3). Our results show that ER/PR expression is not associated with FIGO stage, risk stratification and other risk factors (Table 3). After adjusting for factors known to significantly impact survival, the influence of ER/PR status on DFS is generally decreased but the correlation is still significant (Table 3 ).

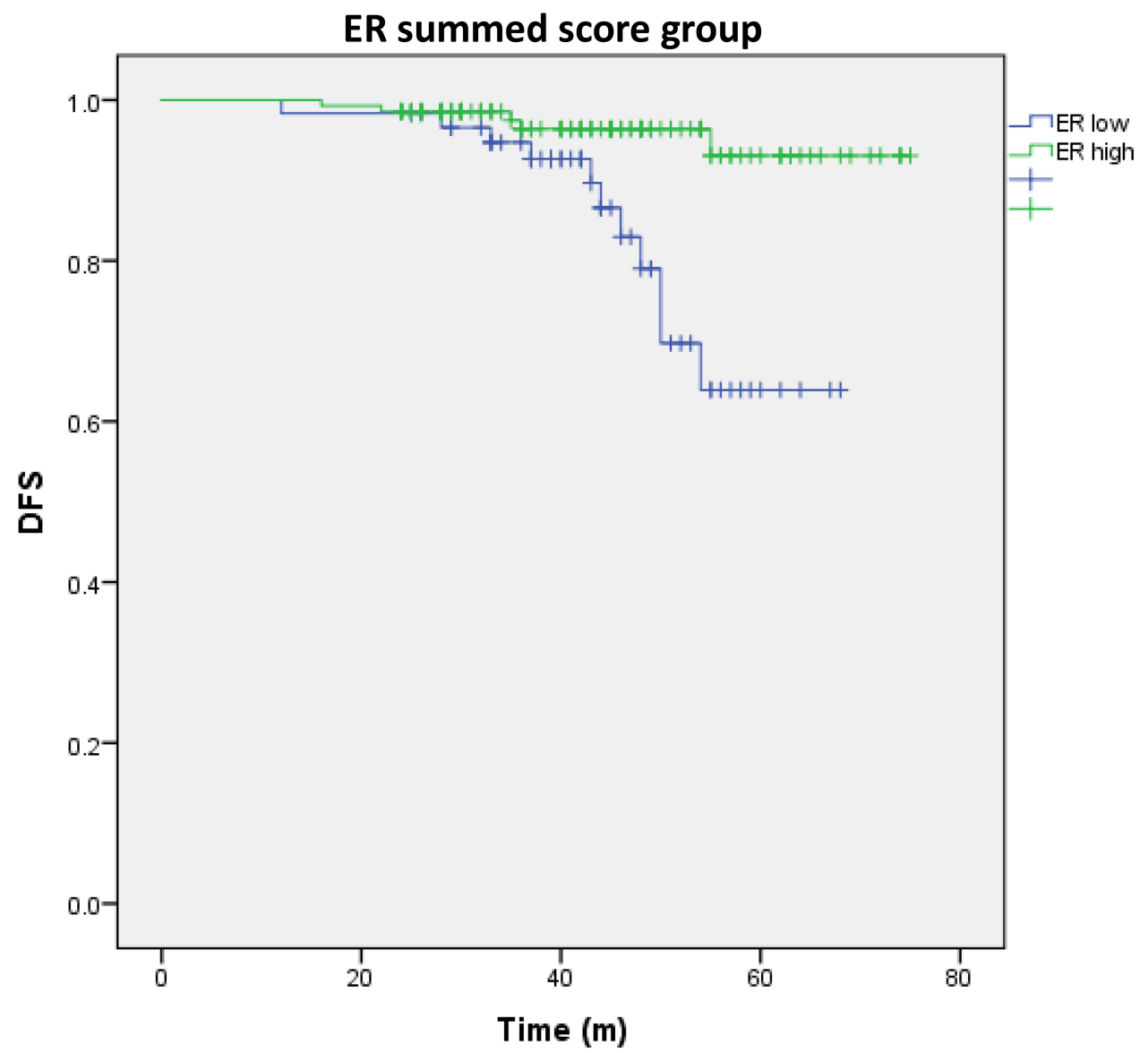

Figure 4 Estimated DFS for Type II endometrial cancer according to ER/PR status. (Kaplan-Meier estimation). Estimated DFS for according to ER/PR combined group. Logrank Test P-value:<0.001. 


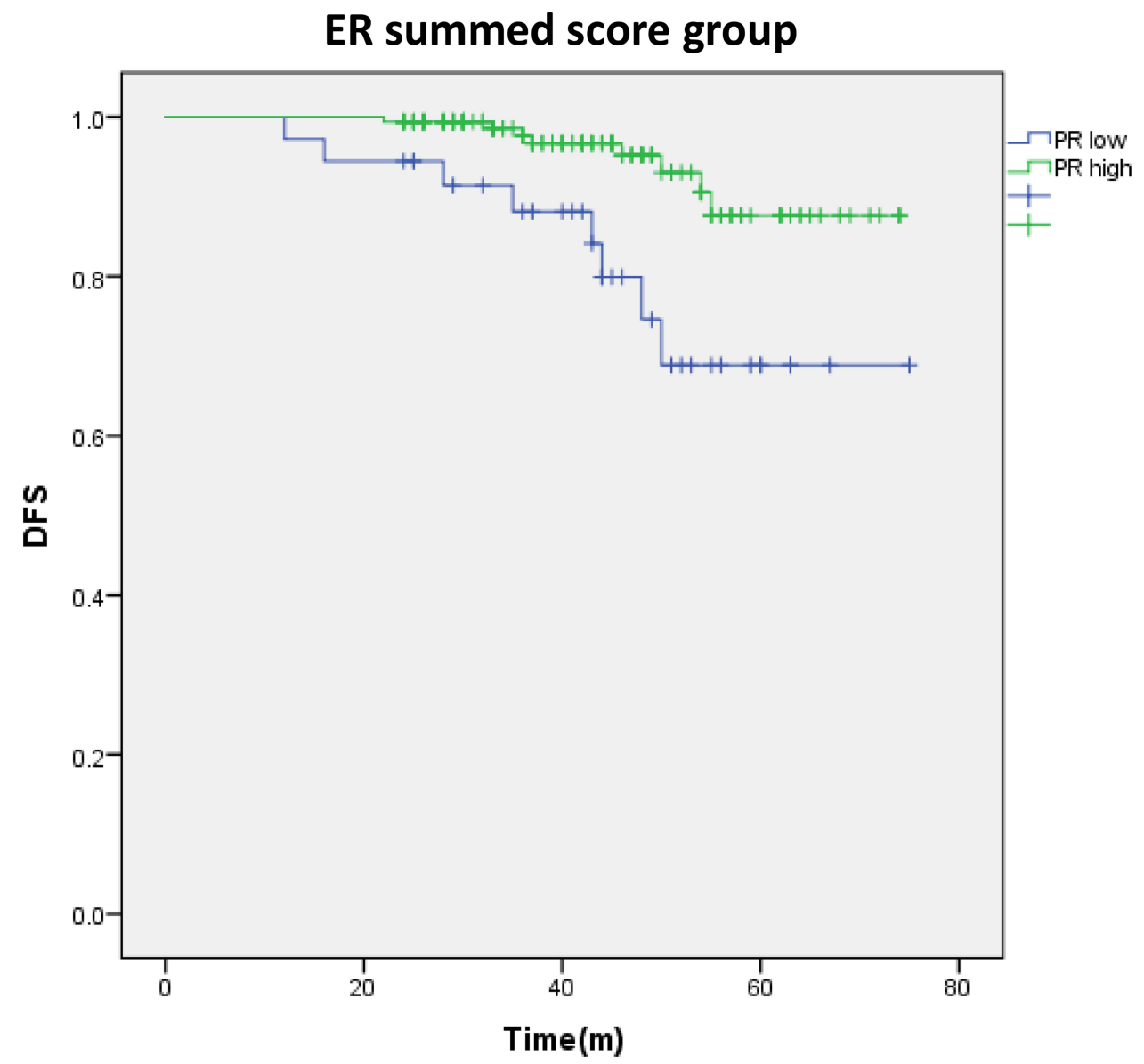

Figure 5 Estimated DFS for Type I endometrial cancer ( $\mathrm{n}=20 \mathrm{I})$ according to ER/PR status (Kaplan Meier estimation). Estimated DFS for according to ER summed score group. Logrank Test $P$ value: $=0.001$.

In the univariate analysis of type II endometrial carcinoma, age $(\mathrm{P}=0.005)$, menopause $(\mathrm{P}=0.022)$, myometrial invasion $(\mathrm{P}=0.007)$, lymph node metastasis $(\mathrm{P}=0.001)$, FIGO stage $(\mathrm{P}<0.001)$, lymph node excision $(\mathrm{P}=0.002)$ were the parameter that had the impact on DFS (Table 1), the intensity, proportion and summed score of ER/PR status were significantly correlated with DFS (Table 4). In the combined ER/PR tumor score group, DFS shows significant advantages in the ER high/PR high group, followed by ER high/PR low, ER low/PR low group (Table 4 and Figure 4). We chose two different Cox regression models to evaluate the correlation between ER/PR states and DFS under different adjustment factors (Table 4). After adjusting for factors known to significantly impact survival, high ER expression is significantly associated with better DFS. However, the effect of PR expression on DFS of type II endometrial cancer is not statistically significant (Table 4).
According to Kaplan-Meier curves for ER/PR expression, patients with higher ER/PR expression showed an overall better DFS (Figures 3-8).

\section{Discussion}

Our study finds that expression of low ER/PR is associated with poorer DFS in patients with type I endometrial cancer. In type II endometrial cancer, lower ER expression is associated with poor DFS, while PR expression has a relatively low effect $(\mathrm{P}>0.05)$.

It is well known that the two types of tumors may have different pathogenesis, In clinical practice, mixed endometrial carcinomas exist in a considerable number of tumors, or due to the heterogeneity of tumors, the diagnosis of the same tumor tissue type and grade by pathologists may be out of sync, leading to challenges in the prognosis and treatment evaluation of patient. ${ }^{13-16}$ A recent study performed an integrated genomic, transcriptomic and proteomic characterization of 373 endometrial carcinomas found 


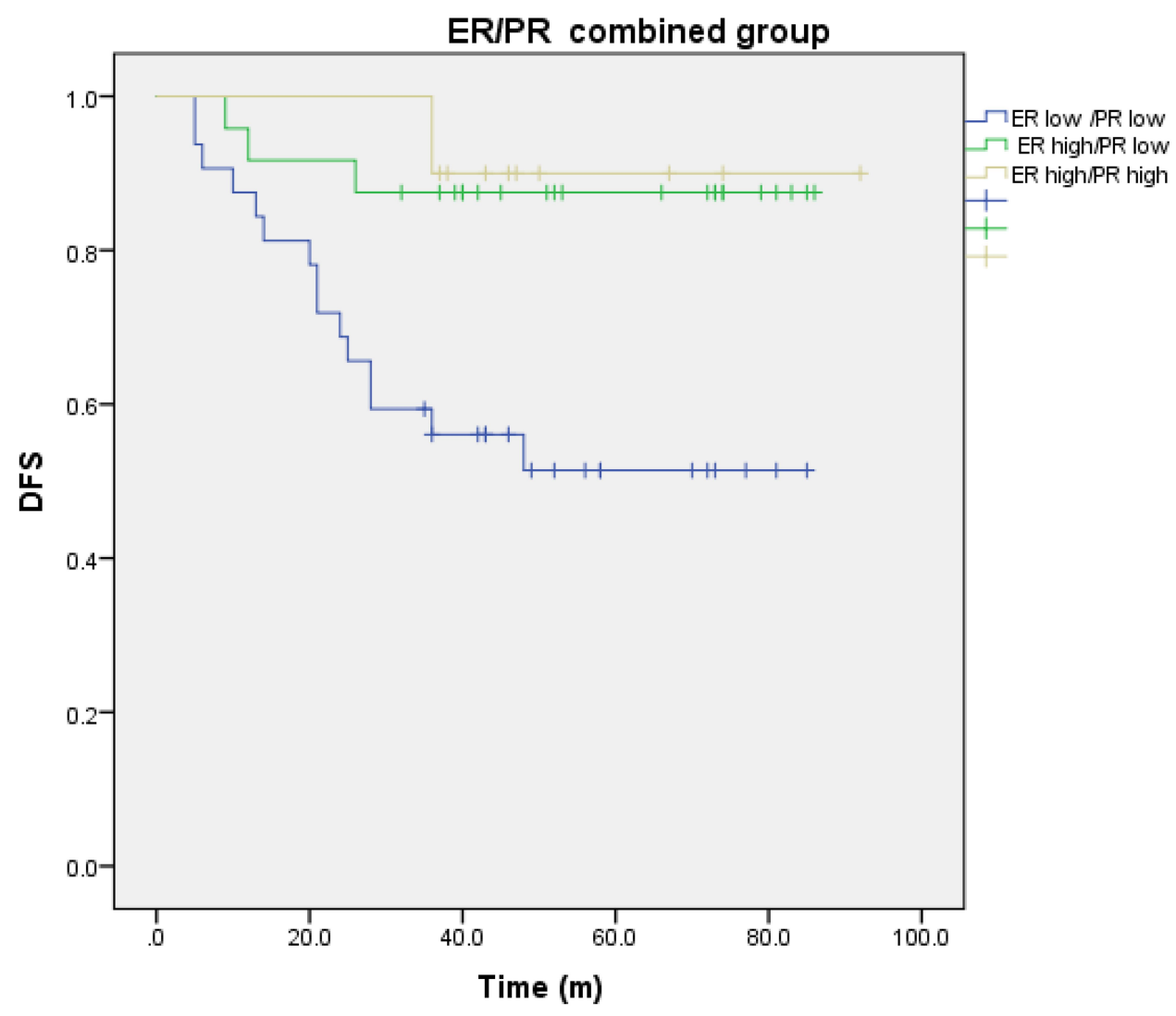

Figure 6 Estimated DFS for Type I endometrial cancer $(n=20 I)$ according to ER/PR status (Kaplan Meier estimation). Estimated DFS for according to P R summed score group. Logrank Test $\mathrm{P}$ value: $=0.003$.

that $25 \%$ of high-grade endometrioid tumors and uterine serous tumors had extensive copy number alterations and low ER/PR status. However, most endometrioid tumors have almost no copy number alterations, mainly manifested by gene stabilization and estrogen signaling activation. ${ }^{3,17}$ Some high-grade endometrial cancers may originate from low-grade endometrial carcinomas, ${ }^{18}$ although some of these may not be estrogen-dependent, ${ }^{19}$ hormone receptor expression is found in approximately $70 \%$ of high-grade endometrioid carcinomas, in $40-60 \%$ of serous carcinomas and $10 \%$ of clear cell carcinomas. ${ }^{20,21}$

In previous articles, some studies have explored the relationship between ER/PR status and prognostic factors of endometrial cancer. However, many studies either do not provide subgroup analysis based on ER and/or PR status or do not have standardized methods or defined cutoff points. In the study of Smith et al, the prognosis of 260 patients with endometrial cancer was studied by analyzing the cutoff point of ER/PR expression, ${ }^{10}$ decreased ER/PR expression is associated with increased tumor-related mortality. However, due to the small number of serous and clear cell carcinomas in their study, they were unable to conduct subgroup analysis and this might have led to biased results due to changes in hormone receptor optimal cut-off value in different pathological types. In a study of 360 patients with endometrial carcinoma, Busch et al note that ER/PR status is associated with cancer-specific survival, but endometrioid tumors predominate $(97 \%)$ and their study examined only the proportion of tumor cell immunohistochemical staining. ${ }^{22}$ In a meta-analysis of 7119 preoperative ER status and 5502 preoperative PR status, high ER/PR expression was associated with better overall survival and DFS, but there is little adjustment for factors known to significantly impact survival. ${ }^{23}$

We use Allred scoring system approaches to define cutpoints for ER/PR status. In the type II endometrial cancer patients, when ER expression reaches $1 \%$, the DFS of patients is relatively better, the PR expression state has no effect on DFS. In type I endometrial cancer group, when ER/PR expression reaches $34 \%$ patients have a relatively better DFS. We found that in both types of endometrial cancer all receptor-negative patients showed a significant decrease in DFS in all intensity assessment 


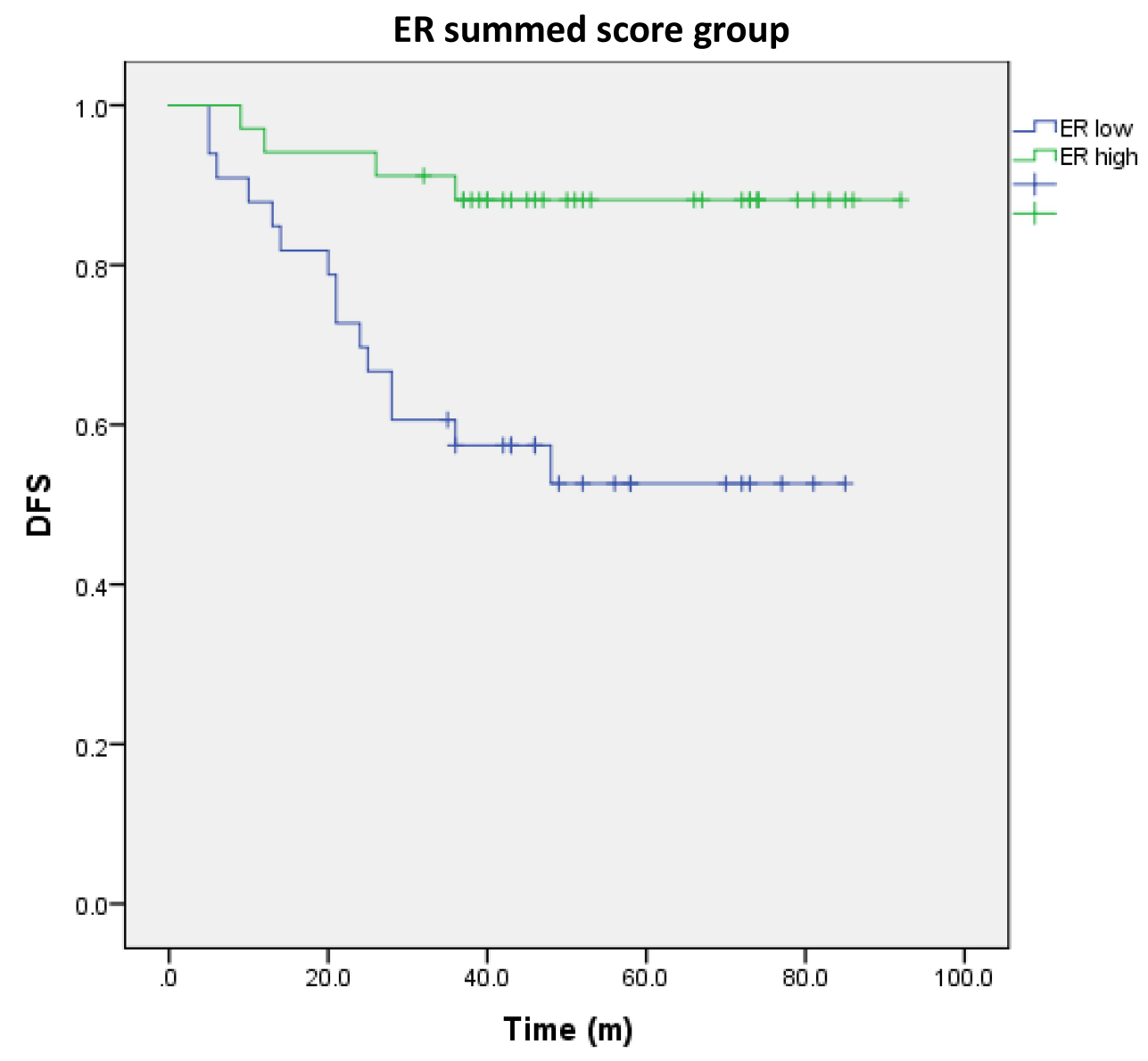

Figure 7 Estimated DFS for Type II endometrial cancer according to ER/PR status. (Kaplan Meier estimation). Estimated DFS for according to ER summed score group. Logrank Test $P$ value: $<0.001$.

groups (Tables 3 and 4). These finding was not associated with pathologic type, grade, FIGO staging, risk stratification, age and other risk factors. Similarly, the subgroup with higher ER expression showed better survival rates in the ER/PR combined group (Figures 3 and 4).

Backes et al use the H-score method to evaluate ER status and they find no association between ER status at the cut-off point of $1 \%$ and overall survival, but estrogen receptor-negative patients showed higher grade and advanced stage disease. ${ }^{24}$ Kothari et al report that the prognosis of $1 \%$ ER positive patients are significantly better than that of those who are completely negative. ${ }^{25}$ Stelloo et al showed a correlation with better prognosis when using $10 \%$ ER cut points. ${ }^{26}$ In the study of ER/PR status and prognosis with positive expression defined in $5 \%$ increments of marker expression, Zhang et al find that higher ER/PR expression is significantly correlated with better prognosis, and PR has a lower cutting point than ER $\left(20 \%\right.$ vs50\%). ${ }^{23}$ Putten et alfind that the loss of PR is the strongest predictor of recurrent disease, but their study has a cutoff point of $10 \%$ for PR and only 15 (5.1\%) nonendometrioid cancers. ${ }^{6}$

At present, the mechanism of ER/PR loss in endometrial cancer has not been widely studied. Studies have shown that the expression of ESR1 and PGR genes was found to be significantly correlated with the expression of ER and PR. ${ }^{27}$ We analyzed the relationship between mutations in ESR1 and PGR genes and DFS in 1800 patients with endometrial cancer from TCGA research network and found that the DFS was significantly decreased in patients with ERS1 gene mutations $(\mathrm{P}<0.001)$, while the effect of PGR gene mutations on DFS was less significant $(\mathrm{P}>0.05)$ (Figures 1 and 2), but this study was based on a general analysis of data on patients with endometrial cancer. Dan He et al analyzed the relationship between mRNA expression of DNMT3A/3B and methylation of ESR1/PGR and prognosis in 544 cases of endometrial cancer from TCGA, and found that overexpression of DNMT3A/3B was significantly correlated with low expression of methylation $\mathrm{ER} / \mathrm{PR}$ and low survival rate in endometrioid cancer, with 


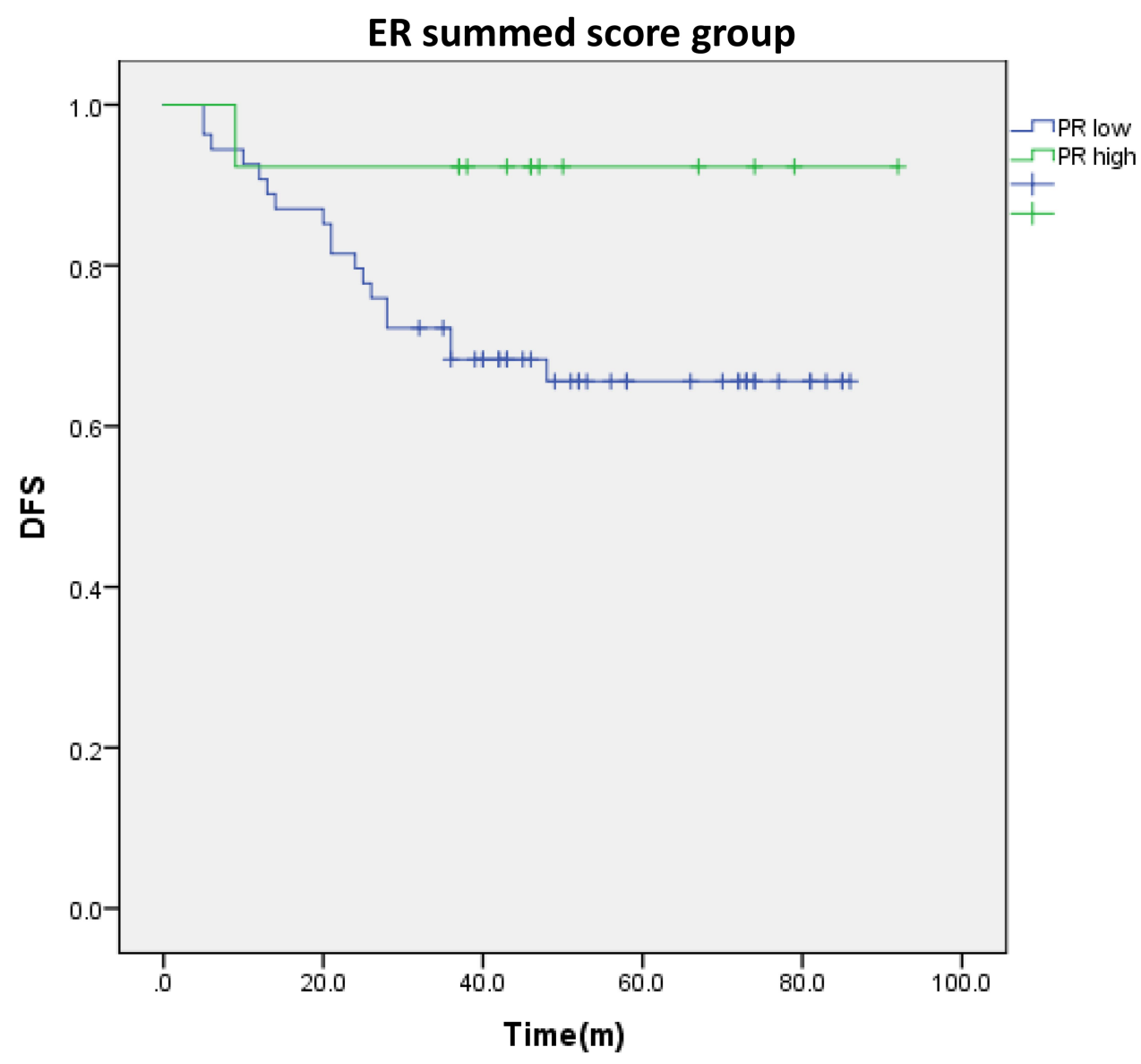

Figure 8 Estimated DFS for Type II endometrial cancer according to ER/PR status (Kaplan Meier estimation). Estimated DFS for according to P R summed score group. Logrank Test $P$ value:=0.105.

relatively minor copy number deletion and relatively small effect of mutation on low expression. However, this pathogenesis may be different in non-endometrioid cancer. The absence and mutation of ESR1 may play a more important role in the downregulation of ER and methylation still has a great influence on the expression of low $\mathrm{PR}^{28}$ At present, the down-regulation mechanism of ER/PR receptor still needs further study.

Other limitations are described as follows. Firstly, our study is a single-center retrospective clinicopathological study, which reduces the prognostic value. Better cutoff points for prognostic biomarkers may be obtained when prospective and randomized clinical trials and standardized methods be performed. At present, the mechanism of estrogen-progesterone receptor loss in endometrial cancer has not been widely studied, and further research on the molecular mechanism may be the key to improve the prognosis of patients with endometrial cancer by targeting immunotherapy ${ }^{9,29}$. Furthermore, in the latest study, according to the genomic features of endometrial cancer, it can be divided into four subtypes: POLE ultramutated, microsatellite instability hypermutated, copy-number low, and copy-number high. ${ }^{17}$ Molecular analysis provides key molecular insights into tumor classification that may have a direct impact on patient treatment recommendations, this will be the focus of our future research. In addition, other clinicopathological factors, such as the association between immunohistochemical staining and lymphatic vessel metastasis, can be included in our recent study to identify new indicators of poor prognosis in patients with endometrial cancer. ${ }^{30}$ Finally, the DNA expression of ESR1/PGR from the TCGA and immunohistochemical of ER/PR expression were not performed in the same cohort, which might generate bias.

\section{Conclusions}

In summary, after adjusting for factors known to significantly impact survival, higher ER/PR expression status was associated with better DFS in patients with type I endometrial cancer, and it is not associated with tumor 
grade, FIGO staging, risk stratification and other risk factors. In patients with type II endometrial cancer, high ER expression is significantly associated with better DFS and it was independent of disease stage; however, the effect of PR expression on DFS is not statistically significant. These findings are significant and rather than simply categorizing endometrial tumors into hormone-dependent and non-hormone-dependent tumors, we may need a more comprehensive and careful interpretation. Evaluation of receptor status in the future may improve the prognosis of patients with endometrial cancer, when women with ER/PR loss should be evaluated to a higher risk group, or at least more clinical attention should be given, and hormone therapy should be emphasized in patients with type ii or advanced disease with high expression of hormone receptors.

\section{Abbreviations}

EC, endometrial carcinoma; DFS, disease-free survival; $\mathrm{ER} / \mathrm{PR}$, estrogen receptor and progesterone receptor; TCGA, The Cancer Genome Atlas research network; WHO, World Health Organization; LVSI, lymphovascular space invasion; FIGO, The International Federation of Gynecology and Obstetrics; IHC, immunohistochemistry; ROC, receiver operating characteristic curve; HR, hazard ratio; $\mathrm{CI}$, confidence interval.

\section{Ethics Approval and Informed Consent}

The institutional review board of institutional research ethics committee of the first affiliated hospital of Chongqing medical university approved this retrospective study in 2019.

\section{Consent for Publication}

The authors declare that the details of any images, videos, and recordings can be published.

\section{Acknowledgments}

We thank all the authors for their undifferentiated contributions. Siling Ren and Jingxian Wu are co-first authors for this study.

\section{Author Contributions}

All authors made substantial contributions to conception and design, acquisition of data, or analysis and interpretation of data; took part in drafting the article or revising it critically for important intellectual content; agreed on the journal to which the article will be submitted; gave final approval of the version to be published; and agree to be accountable for all aspects of the work.

\section{Funding}

There is no funding to report.

\section{Disclosure}

The authors report no conflicts of interest for this work.

\section{References}

1. Ferlay J, Soerjomataram I, Dikshit R, et al. Cancer incidence and mortality worldwide: sources, methods and major patterns in GLOBOCAN 2012. Int $J$ Cancer. 2015;136:E359-E386. doi:10. 1002/ijc. 29210

2. Yang HC, Liu JC, Liu FS. Fertility-preserving treatment of stage IA, well-differentiated endometrial carcinoma in young women with hysteroscopic resection and high-dose progesterone therapy. Taiwan J Obstet Gynecol. 2019;58:90-93. doi:10.1016/j.tjog.2018.11.017

3. Sugiyama Y, Gotoh O, Fukui N, et al. Two distinct tumorigenic processes in endometrial endometrioid adenocarcinoma. $\mathrm{Am}$ J Pathol. 2020;190(1):234-251

4. Guan J, Xie L, Luo X, et al. The prognostic significance of estrogen and progesterone receptors in grade I and II endometrioid endometrial adenocarcinoma: hormone receptors in risk stratification. J Gynecol Oncol. 2019;30(1):e13. doi:10.3802/jgo.2019.30.e13

5. Karnezis AN, Leung S, Magrill J, et al. Evaluation of endometrial carcinoma prognostic immunohistochemistry markers in the context of molecular classification. J Pathol Clin Res. 2017;3:279-293. doi:10.1002/cjp2.82

6. van der Putten LJM, Visser NCM, Van de Vijver K, et al. Added value of estrogen receptor, progesterone receptor, and $\mathrm{L} 1$ cell adhesion molecule expression to histology-based endometrial carcinoma recurrence prediction models an ENITEC Collaboration Study. Int $J$ Gynecol Cancer. 2018;28:514-523. doi:10.1097/IGC.000 0000000001187

7. Gülseren V, Kocaer M, Özdemir İA, Çakır İ, Sancı M, Güngördük K. Do estrogen, progesterone, P53 and Ki67 receptor ratios determined from curettage materials in endometrioid-type endometrial carcinoma predict lymph node metastasis? Curr Probl Cancer. 2019;44 (1): 100498 .

8. Mirza MR. Management of Endometrial Cancer. Switzerland AG: published by the registered company Springer Nature; 2020.

9. Jerzak KJ, Duska L, MacKay HJ. Endocrine therapy in endometrial cancer: an old dog with new tricks. Gynecol Oncol. 2019;153:175-183. doi:10.1016/j.ygyno.2018.12.018

10. Smith D, Stewart CJ, Clarke EM, et al. ER and PR expression and survival after endometrial cancer. Gynecol Oncol. 2018;148:258-266. doi:10.1016/j.ygyno.2017.11.027

11. Yunokawa M, Yoshida H, Watanabe R, et al. Allred score is a promising predictor of prognosis and medroxyprogesterone acetate efficacy in patients with endometrial cancer. Cancer Chemother Pharmacol. 2017;80:127-134. doi:10.1007/s00280-017-3342-5

12. Allred DC, Harvey JM, Berardo M, Clark GM. Prognostic and predictive factors in breast cancer by immunohistochemical analysis. Mod Pathol. 1998;11(2):155-168.

13. Matrai CE, Pirog EC, Ellenson LH. Despite diagnostic morphology, many mixed endometrial carcinomas show unexpected immunohistochemical staining patterns. Int J Gynecol Pathol. 2018;37:405-413. doi:10.1097/PGP.0000000000000443 
14. Carlson JW, Nastic D. High-grade endometrial carcinomas classification with molecular insights. Surg Pathol. 2019;12:343-362. doi:10. 1016/j.path.2019.02.003

15. McConechy MK, Ding J, Cheang MC, et al. Use of mutation profiles to refine the classification of endometrial carcinomas. J Pathol. 2012;228:20-30. doi:10.1002/path.4056

16. Clarke BA, Gilks CB. Endometrial carcinoma: controversies in histopathological assessment of grade and tumour cell type. J Clin Pathol. 2010;63:410-415. doi:10.1136/jcp.2009.071225

17. Levine DA. Cancer genome atlas research network. Integrated genomic characterization of endometrial carcinoma. Nature. 2013;497 (7447):67-73. doi:10.1038/nature 12113

18. Gilks CB, Oliva E, Soslow RA. Poor interobserver reproducibility in the diagnosis of high-grade endometrial carcinoma. Am J Surg Pathol. 2013;37:874-881. doi:10.1097/PAS.0b013e31827f576a

19. Suarez AA, Felix AS, Cohn DE. Bokhman redux: endometrial cancer "types" in the 21st century. Gynecol Oncol. 2017;144:243-249. doi:10.1016/j.ygyno.2016.12.010

20. Köbel M, Atenafu EG, Rambau PF, et al. Progesterone receptor expression is associated with longer overall survival within high-grade histotypes of endometrial carcinoma: a Canadian high risk endometrial cancer consortium (CHREC) study. Gynecol Oncol. 2016;141:559-563. doi:10.1016/j.ygyno.2016.04.008

21. Mhawech-Fauceglia P, Yan L, Liu S, Pejovic T. ER+/PR+/TFF3 +/IMP3 immunoprofile distinguishes endometrioid from serous and clear cell carcinomas of the endometrium: a study of 401 cases. Histopathology. 2013;62:976-985. doi:10.1111/his.12096

22. Busch EL, Crous-Bou M, Prescott J, et al. Endometrial cancer risk factors, hormone receptors, and mortality prediction. Cancer Epidemiol Biomarkers Prev. 2017;26:727-735. doi:10.1158/10559965.EPI-16-0821
23. Zhang Y, Zhao D, Gong C, et al. Prognostic role of hormone receptors in endometrial cancer: a systematic review and meta-analysis. World J Surg Oncol. 2015;13:208.

24. Backes FJ, Walker CJ, Goodfellow PJ, et al. Estrogen receptor-alpha as a predictive biomarker in endometrioid endometrial cancer. Gynecol Oncol. 2016;141:312-317. doi:10.1016/j.ygyno.2016.03.006

25. Kothari R, Morrison C, Richardson D, et al. The prognostic significance of the triple negative phenotype in endometrial cancer. Gynecol Oncol. 2010;118:172-175. doi:10.1016/j.ygyno.2010.04.015

26. Stelloo E, Nout RA, Osse EM, et al. Improved risk assessment by integrating molecular and clinicopathological factors in early-stage endometrial cancer-combined analysis of the PORTEC cohorts. Clin Cancer Res. 2016;22:4215-4224. doi:10.1158/1078-0432.CCR-15-2878

27. Wik E, Ræder MB, Krakstad C, et al. Lack of estrogen receptor- $\alpha$ is associated with epithelial - mesenchymal transition and PI3K alterations in endometrial carcinoma. Clin Cancer Res. 2013;19:1094-1105. doi:10.1158/1078-0432.CCR-12-3039

28. He D, Wang X, Zhang Y, et al. DNMT3A/3B overexpression might be correlated with poor patient survival, hypermethylation and low expression of ESR1/PGR in endometrioid carcinoma: an analysis of the cancer genome atlas. Chin Med J. 2019;132(2):161. doi:10.1097/ CM9.0000000000000054

29. Wortman BG, Nout RA, Bosse T, Creutzberg CL. Selecting adjuvant treatment for endometrial carcinoma using molecular risk factors. Curr Oncol Rep. 2019;21:83. doi:10.1007/s11912-019-0825-z

30. Sorbi F, Projetto E, Irene Turrini I, et al. Luteinizing hormone/human chorionic gonadotropin receptor immunohistochemical score associated with poor prognosis in endometrial cancer patients. Biomed Res Int. 2018;2018:1618056. doi:10.1155/2018/1618056

\section{Publish your work in this journal}

Cancer Management and Research is an international, peer-reviewed open access journal focusing on cancer research and the optimal use of preventative and integrated treatment interventions to achieve improved outcomes, enhanced survival and quality of life for the cancer patient.
The manuscript management system is completely online and includes a very quick and fair peer-review system, which is all easy to use. Visit http://www.dovepress.com/testimonials.php to read real quotes from published authors. 